\section{ZEBRA Batteries}

Hikari Sakaebe

Research Institute for Ubiquitous Energy

Devices, National Institute of Advanced

Industrial Science and Technology (AIST),

Ikeda, Osaka, Japan

\section{Introduction}

ZEBRA battery is actually a Z E B R A (Zeolite $B$ attery Research Africa) battery, that is, sodiumnickel chloride cell. This battery consists of a liquid $\mathrm{Na}$ negative electrode and $\mathrm{NiCl}_{2}$ separated by $\beta$-alumina solid electrolyte with $\mathrm{Na}^{+}$ conduction. Total cell reaction is as follows:

$$
\begin{aligned}
& 2 \mathrm{Na}+\mathrm{NiCl}_{2} \Longleftrightarrow 2 \mathrm{NaCl}+\mathrm{Ni} V \\
& \quad=2.58 \mathrm{~V} \text { at } 300{ }^{\circ} \mathrm{C}
\end{aligned}
$$

This battery system was invented by Johan Coetzer at CSIR (Council for Scientific and Industrial Research) in South Africa. Energy density of ZEBRA battery is relatively high (theoretical $788 \mathrm{Wh} / \mathrm{kg}$, practical $90 \mathrm{Wh} / \mathrm{kg}$ ) among the rechargeable battery. The first patent was applied in 1978. Then this battery system was developed by BETA Research and Development Ltd. in England, and the development was continued. Afterward this was integrated into the joint venture of AEG (later Daimler) and Anglo American Corporation 10 years later. The company AEG Anglo Batteries $\mathrm{GmbH}$ funded by joint venture started the pilot line production of ZEBRA batteries in 1994. After the merger of Daimler and Chrysler, AEG Anglo Batteries GmbH was terminated. MES-DEA succeeded the ZEBRA technology and industrialized the battery. At the time, production capacity was 2,000 battery packs per year in a building designed for a capacity of 30,000 battery packs per year. We can find detailed review in references $[1,2]$.

\section{Composition of the Battery}

\section{Cell Chemistry}

At a charged state, positive and negative electrode could be $\mathrm{NiCl}_{2}$ and $\mathrm{Na}$ metal. It is quite difficult to handle these materials in a production scale, and the cell is usually built with $\mathrm{NaCl}$ and $\mathrm{Ni}$ metal as discharged products. In order to maintain the sufficient utilization of Na electrode, $\mathrm{Al}$ powder is incorporated in the positive electrode side to form $\mathrm{NaAlCl}_{4}$ that can be an electrolyte when the electrode materials are melted. Operation temperature is at around $270-350{ }^{\circ} \mathrm{C}$. Sodium ion conductivity has a practical value $\left(\geq 0.2-1 \mathrm{~cm}^{-1}\right)$ at $260{ }^{\circ} \mathrm{C}$ and is temperature dependent with a positive gradient [3]. Thus, the operational temperature of ZEBRA batteries has been chosen for the range above. Current collector for positive electrode is $\mathrm{Cu}$ wire with Ni plating.

Cell structure is schematically shown in Fig. 1. Outside of $\beta$-alumina electrolyte case, $\mathrm{Na}$ electrode is incorporated in the cell can tube 


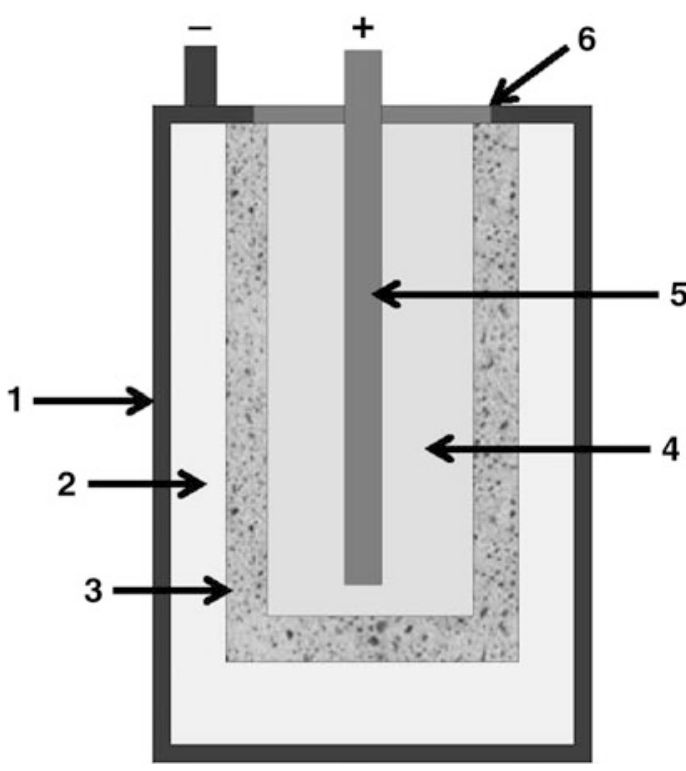

ZEBRA Batteries, Fig. 1 Basic cell structure of ZEBRA battery. 1 Cell can for the $\mathrm{Na}$ negative electrode, $2 \mathrm{Na}$ negative electrode, 3 ceramic electrode tube made of $\beta$-alumina, 4 mixture for the positive electrode $\left(\mathrm{NiCl}_{2}+\right.$ $\mathrm{NaAlCl}_{4}$ ), 5 current collector for positive electrode, 6 thermal compression bond

(stainless steel with $\mathrm{Ni}$ plating), and $\mathrm{NiCl}_{2}$ and $\mathrm{NaAlCl}_{4}$ are inside the $\beta$-alumina tube. Outer cell case is a current collector for Na negative electrode. Molten $\mathrm{Na}$ can be partly isolated in sodium compartment if discharge depth becomes so deep and $\mathrm{Na}$ loses electronic contact with current collector. And thus $100 \%$ utilization for $\mathrm{Na}$ is difficult.

Because of these phenomena, potential drops suddenly at the end of the discharge. This behavior is not desirable for practical use, and Al powder takes part in the additional electrode reaction to alleviate the potential drop.

$\mathrm{Al}+4 \mathrm{NaCl} \Longleftrightarrow 3 \mathrm{Na}+\mathrm{NaAlCl}_{4} V \mathrm{oc}=1.58 \mathrm{~V}$

At the same time, $\mathrm{Al}$ helps $\mathrm{NaAlCl}_{4}$ melt to penetrate into the pores in electrode. Iron sulfide is added in order to stabilize the Ni particle size. The plateau can be found in the potential region in $2-1.6 \mathrm{~V}$.

This salt liquefies at $154{ }^{\circ} \mathrm{C}$, and in the liquid state it is conductive for sodium ions. It has several functions that play very important roles for the ZEBRA battery technology. Concretely, the salt conducts $\mathrm{Na}^{+}$, prevents the cracks of $\beta$-alumina, keeps the safety, and protects the cell from overcharge and overdischarge.

Positive electrode of the cell is theoretically a mixture of $\mathrm{Ni}$ and $\mathrm{NiCl}_{2} \cdot \mathrm{Na}^{+}$conduction in the electrode is not enough, and the liquid salt $\mathrm{NaAlCl}_{4}$ conducts the $\mathrm{Na}^{+}$between the solid electrolyte ceramic surface and the reaction zone inside the positive electrode bulk during the cell operation. With this function, all chemical species in positive electrode can be utilized.

Ceramic is a quite brittle material. By several triggers like a vibration, stress, and so on, cracks may be developed. In this case, through the crack, the liquid salt $\mathrm{NaAlCl}_{4}$ becomes in contact with the liquid sodium (the melting point of sodium is $90{ }^{\circ} \mathrm{C}$ ) to form a salt and $\mathrm{Al}$ metal:

$$
\mathrm{NaAlCl}_{4}+3 \mathrm{Na} \rightarrow 4 \mathrm{NaCl}+\mathrm{Al}
$$

Small cracks in the ceramic electrolyte can be closed by formed salt and Al. When crack is larger, formed $\mathrm{Al}$ short-circuits between positive and negative electrode. This cell loses voltages, but still the whole system can be operated as long as failed cell was within $5-10 \%$ of the total cells. The battery controller detects this and adjusts all operative parameters. In this meaning, ZEBRA battery is failure tolerant to some extent.

The same reaction helps to passivate the positive electrode material $\left(\mathrm{NiCl}_{2}\right)$. In this sequence, some energy is released, but the total energy can be reduced almost $30 \%$ of the normal and full reaction in discharging.

The charge capacity of the ZEBRA cell is governed by the quantity of $\mathrm{NaCl}$ available in the positive electrode. During an operation, the liquid salt $\mathrm{NaAlCl}_{4}$ is a $\mathrm{Na}$ reserve as shown in the following reaction:

$$
2 \mathrm{NaAlCl}_{4}+\mathrm{Ni} \leftrightarrow 2 \mathrm{Na}+2 \mathrm{AlCl}_{3}+\mathrm{NiCl}_{2}
$$

This corresponds to an overcharge reaction and requires a higher voltage than $3.05 \mathrm{~V}$.

When the cell is overdischarged, the same reaction with the case of cell failure occurs at $1.58 \mathrm{~V}$. 


\section{ZEBRA Batteries,}

Fig. 2 First charge and discharge curves of $\mathrm{Na}$ / $\mathrm{NiCl}_{2}$ cell without additives assembled in discharged state (Reproduced figure from Ref. [4])

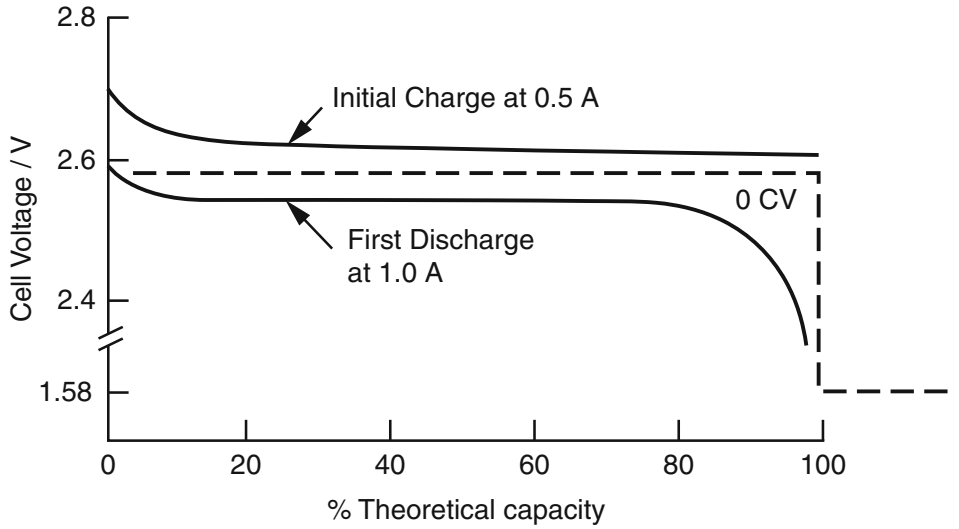

Charged
Discharged

\section{Battery Design}

Cells are connected in parallel and in series combination. Dustmann at MES-DEA S. A introduced some example [1]. Types of battery vary with one to five parallel strings, up to 220 cells in series and 100-500 cells in one battery pack. The standard battery type Z5C (32 or $64 \mathrm{Ah}$ as nominal capacity and 557 or $278.6 \mathrm{~V}$ as OCV, respectively) has 216 cells arranged in one $(\mathrm{OCV}=557 \mathrm{~V})$ or two $(\mathrm{OCV}=278 \mathrm{~V})$ strings. Cooling plate separates each second cell, through which ambient air is circulated. Cooling power is 1.6-2 kW. Cells are surrounded by a doublewalled vacuum insulation for thermal insulation. The thickness of walls is typically $25 \mathrm{~mm}$. This configuration has a heat conductivity of only $0.006 \mathrm{~W} / \mathrm{mK}$ and is stable for up to $1,000{ }^{\circ} \mathrm{C}$.

\section{Battery System Design}

The complete system ready for assembly is equipped with the ohmic heater, the fan for cooling, and the battery management interface (BMI) [1]. BMI controls the thermal issues and electrical connection through a main circuit breaker that can disconnect the battery from outside. The BMI measures and supervises a lot of parameters: voltage, current, status of charge, and insulation resistance of negative and positive pole to ground. It controls the charger by a dedicated pulse width modulated (PWM) signal.
A CAN bus is used for the communication between the BMI and devices. All battery data are monitored for diagnostic with a notebook.

\section{Performance}

There is no side reaction in the cell chemistry of ZEBRA battery, and therefore, the charge and discharge cycle has almost $100 \%$ efficiency. This is due to the ceramic electrolyte. Figure 2 shows a first charge and discharge curves of $\mathrm{Na} / \mathrm{NiCl}_{2}$ cell assembled in a discharged state [4]. This cell contains no additives like FeS.

Discharge curves of cell in practical battery system are slightly different from Fig. 2. Figure 3 is an example for the discharge curves of ML/3I 32 Ah cell reported by J.L. Sudworth at Beta Research and Development Ltd. [5]. At around $2.35 \mathrm{~V}, \mathrm{Fe}$ species is involved in the cell reaction:

$$
\begin{aligned}
& \mathrm{FeS}+2 \mathrm{NaCl}+\mathrm{Ni} \rightarrow \mathrm{FeCl}_{2}+\mathrm{NiS}+2 \mathrm{Na} V \\
&=2.37 \mathrm{~V} \\
& \mathrm{FeCl}_{2}+2 \mathrm{Na} \rightarrow \mathrm{Fe}+2 \mathrm{Na} \quad V=2.35 \mathrm{~V}
\end{aligned}
$$

Charging of ZEBRA cells and batteries is at a $6 \mathrm{~h}$ rate for normal charge and $1 \mathrm{~h}$ rate for 
ZEBRA Batteries,

Fig. 3 Discharge curves of the ML/3I 32 Ah cells at 1.5 A (Reproduced from the figure in Ref. [5])

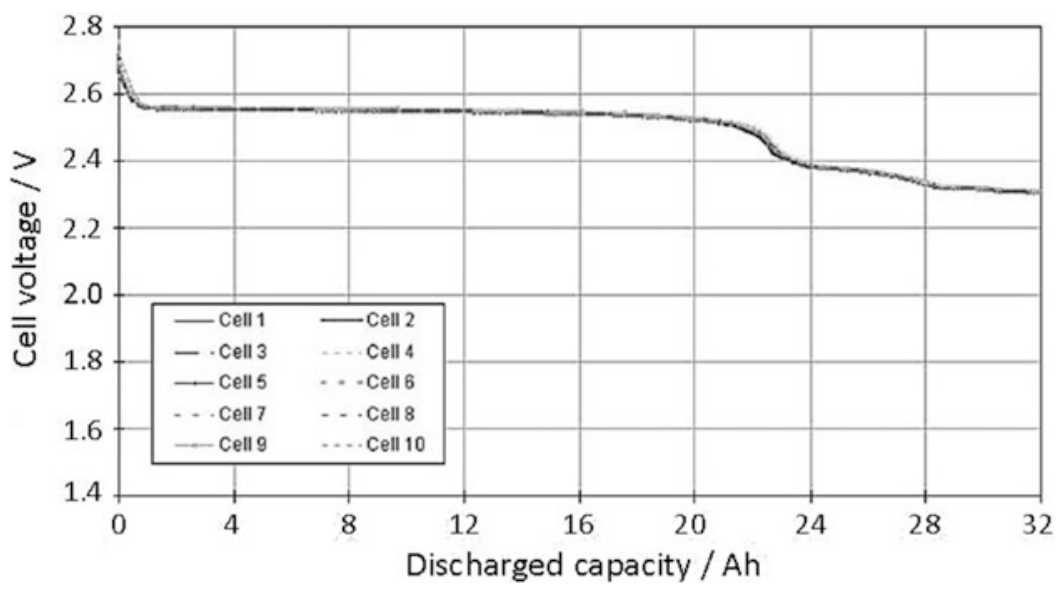

fast charge. The voltage limitation differs depending on the mode. Limitation is set per cell and $2.67 \mathrm{~V}$ and $2.85 \mathrm{~V}$ for normal and fast charge, respectively. Fast charging mode does not allow the charge over $80 \%$ SOC. Regenerative breaking is limited to $3.1 \mathrm{~V}$ and 60 A per cell so that high regenerative breaking rates are possible. The peak power during discharge is independent of SOC when it is defined as the power at $67 \%$ OCV. It is generally reported that the power density of this battery is $150 \mathrm{~W} / \mathrm{kg}$. Specific power depends on the operation mode of positive electrode. Detailed mechanism is described in references $[2,3,5]$.

Battery life is specified as calendar and cycle life. Factors that limit the life are corrosion, resistance rise, and capacity loss [5]. Without electrochemical operation, cell slowly degrades, but the calendar life of 11 years is demonstrated [1]. The cycle life is measured by the accumulation of all discharged charge measured in Ah divided by the nominal capacity in Ah. Each cycle for nominal capacity is equivalent to a $100 \%$ discharge cycle. The expected cycle life is up to 3,500 cycles [1] from module tests and 1,450 cycles from battery testing [1] that simulated all real-life operation conditions. The thermal insulation was stable for more than 15 years in the report of C. H. Dustmann [1].

\section{Battery Safety}

Battery safety is so important for mobile and vehicle applications. Especially for vehicles, on the road, accident likely becomes heavy, and the crash accident should not bring more danger by release of the energy stored in the cells. And various tests are usually conducted. In ZEBRA battery case, test results were reported. Crash of an operative battery against a pole with $50 \mathrm{~km} / \mathrm{h}$, overcharge test, overdischarge test, short circuit test, vibration test, external fire test, and submersion of the battery in water have been specified and performed [6]. The ZEBRA battery did pass all these tests owing to its four-barrier safety concept $[7,8]$ : chemical aspects, cell case, thermal structure, and battery controller.

As commented in "Cell Chemistry," mechanical damage in a ceramic electrolyte is recovered even in the mechanical damage. And liquid electrolyte reacted with the liquid sodium forms layer of salt and aluminum equal to the overcharge reaction. This reaction reduces the thermal load by about $1 / 3$ compared to the total electrochemically stored energy. Cell case was closed by TCB to stand up to $900{ }^{\circ} \mathrm{C}$. Thermal insulation material is made out of foamed $\mathrm{SiO}_{2}$. This is thermally stable over $1,000{ }^{\circ} \mathrm{C}$, and the heat conductivity is very low (only $0.006 \mathrm{~W} / \mathrm{mK}$ ) in the vacuum insulation box. Even when the vacuum environment 
is broken, heat conductivity increased only by a factor of three, and this is still possible to insulate the heat. Also as stated in "Battery System," BMI senses the thermal failure and controls the cell operation.

\section{Applications}

The ZEBRA battery system has been designed for mainly electric vehicles. This application requires both of power and energy. ZEBRA battery has a sufficient balance of power and energy and a candidate system of the practical EV. Other applications are electric vans, buses, and hybrid buses with ZEV range. For these applications, ZEBRA battery requires some devices to maintain the temperature for quick start. Once the battery is cooled down to room temperature, it usually takes 1-2 days to be operated. In this meaning, continuous operation like a stationary use may be favorable. Telecommunication or marine use is also a possible application. Hybrid system concept of solid oxide fuel cell and ZEBRA battery for automotive application is designed, and possibility of the system is discussed by D. J. L. Brett et al. [9]. This kind of hybrid system may improve energy efficiency making use of the heat from fuel cells.

\section{References}

1. Dustmann CH (2004) Advances in ZEBRA batteries. J Power Sources 127:85-92

2. Sudworth JL, Galloway RC (2009) Secondary batteries - high temperature systems - sodium-nickel chloride. In: Jürgen Garche, et al. Encyclopedia of electrochemical power sources. Amsterdam, The Nederland Elsevier BV, p 312

3. Sudworth JL, Tilley AR (1985) The sodium sulphur battery. Chapman \& Hall, London

4. Bones RJ, Teagle DA, Brooker SD, Cullen FL (1989) Development of a $\mathrm{Ni}, \mathrm{NiCI}_{2}$ positive electrode for a liquid sodium (ZEBRA) battery cell. J Electrochem Soc 136:1274-1277

5. Sudworth JL (2001) The sodium/nickel chloride (ZEBRA) battery. J Power Sources 100:149-163

6. Böhm H, Bull RN, Prassek A (1989) ZEBRA's response to the new EUCAR/USABC abuse test procedures, EVS-15, Brussels, 29 Sept-3 Oct

7. Zyl AV, Dustmann CH (1995) Safety aspects of ZEBRA high energy batteries. evt95, Paris, 13-15 Nov 57

8. Trickett D, Current Status of Health and Safety Issues of Sodium/Metal Chloride (ZEBRA) Batteries (1998) National renewable energy laboratory report, TP-460-25553

9. Brett DJL, Aguiar P, Brandon NP, Bull RN, Galloway RC, Hayes GW, Lillie K, Mellors C, Smith C, Tilley AR (2006) Concept and system design for a ZEBRA battery-intermediate temperature solid oxide fuel cell hybrid vehicle. Concept and system design for a ZEBRA battery-mediate. J Power Sources 157:782-798 


\title{
Publisher's Erratum to: Boron-Doped Diamond for Green Electro-Organic Synthesis
}

\author{
Siegfried R. Waldvogel and Bernd Elsler \\ Department for Organic Chemistry, Johannes Gutenberg University Mainz, Mainz, Germany \\ waldvogel@uni-mainz.de \\ elsler@uni-mainz.de
}

Owing to an unfortunate oversight on the part of Springer, the second author Bernd Elsler was missing in the initially published version of this contribution. 